\title{
Makerspace: Innovation in Mechanical Engineering Education
}

\author{
Makerspace: Makina Mühendisliği Eğitiminde İnovasyon
}

\author{
Elif BENGÜ, Emin Faruk KEÇECi
}

\begin{abstract}
The complexity of industrial developments requires engineering students to have hands on experience as well as theoretical engineering knowledge. There is a need for a change of classical engineering curriculums. Makerspaces can be a crucial part of this change. They are introduced as physical locations where engineering student's curiosity is fed and solutions to problems are found through teamwork. Their use in higher education can also provide an opportunity for students to engage in experiential learning. They can develop a large range of soft skills that traditional undergraduate curriculum is unable to provide, such as planning, teamwork, critical thinking and communication. There are still limited studies about the full effect and impact of these spaces in teaching and learning, from the pedagogical perspective. The aim of this study is to determine students' experiences with such spaces and examine how makerspaces are contributing to their learning. Descriptive research method (one-on-one interviews and normative survey) were used to evaluate students, graduate assistants and a faculty members' perception of the space and depict the situation. The results of this study showed that students want more than theoretical knowledge from their engineering education. They want to be able to gain hands on experience while they are learning theory. While designing a makerspace for that purpose, the sustainability and the functioning of these spaces should be taken into consideration. The findings of this study can provide guidance for the institutions that are planning to build a makerspace in their campuses.
\end{abstract}

Keywords: Makerspace, Higher education, Engineering education, Innovation, Hands-on learning

\section{ÖZ}

Gelişen endüstrinin karmaşıklı̆ı̆, mühendislik öğrencilerinin teorik mühendislik bilgilerinin yanı sıra deneyime de sahip olmalarını gerektirir. Klasik mühendislik müfredatlarının değiştirilmesine ihtiyaç vardır. Makerspace bu değişikliğin önemli bir parçası olabilir. Bu alanlar, mühendislik öğrencilerinin merakının beslendiği ve ekip çalı̧ması yoluyla sorunlara çözümlerin bulunduğu fiziksel yerler olarak tanımlanmaktadır. Yükseköğretimde kullanımları, öğrencilerin deneyimsel öğrenmeye katılımları için bir firsat sağlamaktadır. Geleneksel lisans müfredatının veremediği planlama, ekip çalışması, eleştirel düşünme ve iletişim gibi beceriler bu şekilde geliştirebilirler. Pedagojik perspektiften bakıldığında ise, bu alanların öğretim ve öğrenmedeki önemi ve etkileri hakkında hâlen sınırlı sayıda çalı̧ma bulunmaktadır. $\mathrm{Bu}$ çalışmanın amacı öğrencilerin bu tür alanlardaki deneyimlerini belirlemek ve bu alanların öğrenmelerine nasıl katkıda bulunduğunu incelemektir. Öğrencilerin, araştırma görevlilerinin ve bu alanı kuran öğretim üyesinin mekâna ilişkin algısını değerlendirmek ve durumu tasvir etmek için amacıyla tanımlayıcı araştırma yöntemi (bire bir görüşmeler ve normatif anket) kullanılmıştır. Sonuçlar, öğrencilerin mühendislik eğitimlerinden teorik bilgilerden fazlasını istediğini göstermiştir. Teori öğrenirken aynı zamanda tecrübe de kazanmak istemektedirler. $\mathrm{Bu}$ amaçla bir makerspace tasarlanırken, bu alanların sürdürülebilirliği ve işleyişi de dikkate alınmalıdır. Bu çalışmanın bulguları, kampüslerinde bir makerspace kurmayı planlayan kurumlara rehberlik edebilir.

Anahtar Sözcükler: Makerspace, Yükseköğretim, Mühendislik eğitimi, İnovasyon, Yaparak öğrenme

Bengü E., \& Keçeci E. F. (2021). Makerspace: Innovation in mechanical engineering education. Journal of Higher Education and Science/Yükseköğretim ve Bilim Dergisi, 11(1), 207-213. https://doi.org/10.5961/jhes.2021.442

Literature Review of this study was presented at the 3rd Annual International Conference on Engineering Education, 4-7 June 2018, Athens, Greece.

Bu çalışmanın Literatür Taraması 3. Uluslararası Mühendislik Eğitimi Konferansı'nda 4-7 Haziran 2018, Atina, Yunanistan'da sunulmuştur.

Elif BENGÜ (四)

ORCID ID: 0000-0001-9817-7207

Abdullah Gul University, Faculty of Educational Science, Kayseri, Turkey

Abdullah Gül Üniversitesi, Eğitim Bilimleri Fakültesi, Kayseri, Türkiye

elifbengu.edd@gmail.com

Emin Faruk KEÇECi

ORCID ID: 0000-0001-8561-6960

Abdullah Gul University, Faculty of Engineering, Kayseri, Turkey

Abdullah Gül Üniversitesi, Mühendislik Fakültesi, Kayseri, Türkiye

Received/Geliş Tarihi : 27.05.2020

Accepted/Kabul Tarihi : 24.04.2021 


\section{INTRODUCTION}

The concept of a makerspace is not a new concept, but it is a newly derived term and is based on the maker movement (Hatch, 2014). However, the use of these spaces in engineering education is new and has been creating a new era in education. In education, a makerspace is defined as a space where students and professionals come together to think, explore, and create something by using tools and materials (Burke, 2015; Roffey, Sverko \& Therien, 2016; Stager, 2014). It provides students an experiential learning environment through tools and activities such as design, prototyping, 3D printing, manufacturing and/or programming. The space provides students with the opportunity to develop and demonstrate $21^{\text {st }}$ century skills such as creativity, innovation, independence, collaboration, communication, teamwork, critical thinking and problem-solving (Barak, 2013; Dede, 2009; Lanci et al., 2018; Wong \& Partridge, 2016) that are essential to the profession of engineering (Lanci et al., 2018 \& Saorin et al., 2017). Constructivist education has been using makerspaces as a vehicle to develop students' creativity (Hilton et al., 2020; Saorin et al., 2017), self-efficiency (Hilton et al., 2020) and selflearning skills (Stager, 2014) that can be beneficial for students when they need to reskill themselves for the labor market.

\section{Statement of the Problem}

The literature review shows that mechanical engineering education is transforming and the main aspects of these changes can be categorized as;

1) Engineering problems are becoming more interdisciplinary and engineering students need to learn the basic concepts of other fields. Thus, students can work more efficiently and create projects together with students from other engineering disciplines (Kececi, 2017; Myers, 2015; Saorin et al., 2017).

2) Students need a learning environment that sparks their creativity and reasons to apply what they have learned (Barak, 2013; Beanland \& Hadgraft, 2014; Saorin et al., 2017).

3) Instead of a classical and disciplinary oriented engineering curriculum, students also need an interdisciplinary and constructivist-based curriculum that will help them to develop and demonstrate so-called $21^{\text {st }}$ century skills (Hilton et al., 2020; Lanci et al., 2018; Shay, 2012).

4) The global employment crisis and future work emphasize the urgency of upskilling and reskilling to prepare students for the $21^{\text {st }}$ century labor market (Bengu et al. 2020; Hilton et al., 2020; Lanci et al., 2018).

When Shay (2012) mentioned "the curriculum of the future" in his study, he affirms the need for disciplines to transcend theory. In this way, graduates will be able to "shift from conceptual learning to learning through inquiry" (Sheffield et al., 2017) where they will gain critical competence and ability to produce solutions. Innovative institutions aiming to train people with skills for today's multi-dimensional career settings should incorporate constructivism, a learning approach, into their curricula. The main purpose of constructivism is to create new information while interacting with the physical objects that the learners create (Roffey et al., 2015). This new curriculum calls for a space where students and professionals come together to think, explore, and create something by using the tools and materials provided in their fields. This mechanism is defined as makerspace (Burke, 2015; Roffey et al., 2016; Stager, 2014) and it originates from the maker movement (Hatch, 2014).

In 2017, Blackley et al. conducted a case study on a makerspace after a call for action to strengthen STEM in Australia. In their study, they used a makerspace as a pedagogical tool for integrated STEM education and investigated the impact of the place on students' learning. They found out that as female students participate in projects, these spaces provide opportunities for them to engage in a creative way and also inspire all of the participants to plan, research, design, build and apply their theoretical knowledge to hands-on activities (Sheffield et al., 2017).

In order to make engineering education interdisciplinary and practical, approximately 44 universities in the US, more than 5 universities in Europe and 15 universities in Australia have formed makerspaces under different names (Idea Lab, Hackerspace, Think Lab, FabLab or Make Studio) (Kececi, 2017). As stated in the field research, institutions that want to include makerspaces on university campuses are increasing day by day. As Wilczynski (2015) pointed out in his study, the institutions offering engineering education went beyond theory and started embedded project-based courses to create the atmosphere and conditions that students will encounter in their professional life. They began to include practices involving "design-test-build" activities. These activities differentiate makerspaces from classical laboratories or workshops that existed in the classical engineering education.

In Turkey, there are so far 11 makerspaces but not all of them are working under academia. This particular center in this paper, the Make, is located at a public research university in the region of Anatolia. The Make is the first one in its category since it is non-profit and the first one to be established at a public university. Moreover, it is used with the mechanical engineering curriculum to allow the students to gain muchneeded skills as well as practical knowledge. Furthermore, it is built to serve all disciplines of engineering in the university.

\section{Purpose of the Study}

The aim of the research presented in this study is to determine:

a. The contribution of a makerspace to engineering students' learning experience,

\section{b. Makerspaces' effect on students' motivation and}

c. A need of common study space for interdisciplinary studies.

The Make, which is located at a public university, was used to collect the data. The data was collected from the instructor that was established the space, undergraduate students and graduate assistants that have been using the space. Based 
on the definitions in the field, in this study the makerspace is defined as a space where students and faculty members from different disciplines get together to work on a small or big scale engineering project.

\section{The Make}

The institution, AGU, where the Make is located is a small, public research institution that was established in 2013. The university emphasizes education, research and the utilization of knowledge by applying innovative teaching methods, such as active learning, hands on experience, experiential learning and mentored research to its academic courses (Bengu \& Sebnem, 2018).

The Make was established with funding from the Engineering School of the institution in 2017 to be operated by student staff after examining the existing ones in the USA. During the operation of the Make, 4 different expenses were occurred: consumables, machine costs, lost tools and service and fixing cost. The biggest consumable spending was the filaments for the 3D printers. The aim was to observe the operation of the space and increase the number of machines and manufacturing capabilities according to the needs of the projects and students. With this vision, a laser cutting machine, a CNC milling and a $\mathrm{CNC}$ lathe machines were purchased. In the meantime, some of the small hand tools either were damaged or got lost. The Department of Mechanical Engineering needed to allocate special funds to purchase these kinds of tools every year. The service and fixing costs for the 3D printers, which have been used by almost 200 students and around 10 faculty and staff were substantial.

The current rector of the university was aware of the importance of hands-on experience in Mechanical Engineering education and with his vision all the expenses of the Make were paid from the School of Engineering budget. Şahin and Tosun's (2018) descriptive research, emphasized the need for such state support to build these spaces.

The Make is primarily intended for engineering and interdisciplinary projects. There is no fee to use the Make at this point and it is open to all university members. The Department of Mechanical Engineering redesigned its curriculum and courses to enable students to use this space. The space has all kinds of hand tools, lathes, milling machines, all kinds of power tools, carpenter machines for wood processing, 28 different 3D printers in 5 different brands and models. 3D printers followed by the laser cutter are the most commonly stated pieces of equipment in the studies from U.S. and Australia. According to the experiment conducted by Saorin et al. in 2017, computers with 3D software, 3D printers and 3D scanners that are used in a learning environment can boost the creativity of students.

The Make was designed as a place to provide students with practical experience by teaching technical knowledge and theoretical understanding. In order to improve student's learning experience, the department implements design projects into their curriculum where students are active, learning by themselves and through peer-learning.
At the time this study was conducted, the Make was open two hours a day, one hour in the morning and one hour in the afternoon, outside class hours. Priority in machinery use is given to students conducting final-year projects, a practice learned from the University of Texas, Austin and Rice. Training is offered by students and is published through a website established by the students. The aim is to provide a peer-topeer learning environment by providing interaction between students in upper and lower classes. The Make is not open for those outside the university at this point. However, in the future, it may be open to work with a partner in industry that comes with inclusive projects for their students.

\section{New curriculum}

In the mechanical engineering department, the students take a total of 50 courses. Some of these courses are common courses such as GLB (global initiative) and history courses. Departmental courses are basic courses that almost every university offers, such as mechanics, fluid mechanics and manufacturing. The difference and the success of a program lies in the way these courses are taught. A makerspace can be a crucial learning tool at this point, since it can provide a mechanism for students to experiment hands-on and learn outside the classroom (Burke, 2015) and build $21^{\text {st }}$ century competencies, such as critical thinking and teamwork.

The fundamental addition at this institution is the newly designed curriculum (Table 1 ) to provide students an environment to learn by doing. There are 16 courses in pairs where students learn a basic theory and then apply it to a project in the following term to understand the application of theoretical knowledge. They are encouraged to work in teams and expected to create prototypes of their designs. These courses are shown in Table 2.

\section{METHODOLOGY}

Exploratory case study was chosen as a methodology to understand participants' engagement with the space and their reflections on how a makerspace changed their learning experiences. The focus was to establish an understanding of how best to proceed for later investigation in a future study project and whether the methodology was effective in regards to data collection. To assess students' engagement, researchers chose a qualitative perspective. The project was started in Fall 2017 and ended in the middle of the 2019 Fall semester.

\section{Participants}

The first set of data was collected through one-on-one meetings with 5 undergraduate students from Mechanical Engineering and 3 graduate assistants from Mechanical Engineering who had been using the space. These participants were interviewed to evaluate their perception of the space. Following that, the researcher interviewed a faculty member from Mechanical Engineering who established the Make. The interviews lasted approximately 30 minutes. The new curriculum was also examined since it was redesigned to encourage students to experiment and learn outside the classroom (Burke, 2015). The results were compiled using the details to create a final 
Table 1: The Mechanical Engineering Course Program

\begin{tabular}{|c|c|c|c|c|c|c|c|c|}
\hline & $\overline{\overline{\mathbb{1}}}$ & $\begin{array}{c}\text { ME } 101 \text { Technical } \\
\text { Drawing }\end{array}$ & $\begin{array}{l}\text { ME } 103 \\
\text { Engineering } \\
\text { Math I }\end{array}$ & SCI Elective I & SCI Elective II & GLB 101 & ENG 101 & \\
\hline 1 & 音 & $\begin{array}{c}\text { ME } 102 \\
\text { Engineering } \\
\text { Innovation and } \\
\text { Programming }\end{array}$ & $\begin{array}{c}\text { ME } 104 \\
\text { Engineering } \\
\text { Math II }\end{array}$ & $\begin{array}{c}\text { ME } 106 \\
\text { Mechanics I }\end{array}$ & $\begin{array}{c}\text { ME } 108 \text { Materials } \\
\text { Sciences }\end{array}$ & GLB 102 & ENG 102 & \\
\hline 2 & 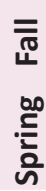 & $\begin{array}{l}\text { ME } 205 \text { Mech. } \\
\text { Eng. Labs. } \\
\text { ME } 202 \text { Fluid } \\
\text { System Design }\end{array}$ & $\begin{array}{c}\text { ME } 207 \text { Fluid } \\
\text { Dynamics } \\
\text { ME } 204 \text { Strength }\end{array}$ & $\begin{array}{c}\text { ME } 209 \text { Materials } \\
\text { Design } \\
\text { ME } 206 \\
\text { Mechanics II }\end{array}$ & $\begin{array}{l}\text { SCI Elective III } \\
\text { SCI Elective IV }\end{array}$ & $\begin{array}{l}\text { GLB } 201 \\
\text { GLB } 202\end{array}$ & $\begin{array}{l}\text { TURK } 101 \\
\text { Turkish I } \\
\text { HIST } 101 \\
\text { History I }\end{array}$ & \\
\hline 3 & ํํำ & $\begin{array}{l}\text { ME } 301 \text { Machine } \\
\text { Elements I } \\
\text { ME } 302 \text { Machine } \\
\text { Elements II }\end{array}$ & $\begin{array}{c}\text { ME } 303 \\
\text { Manufacturing } \\
\text { ME } 304 \\
\text { Mechatronics } \\
\text { and } \\
\text { Measurements }\end{array}$ & $\begin{array}{c}\text { ME } 305 \text { System } \\
\text { Dynamics and } \\
\text { Controls } \\
\text { ME } 306 \text { Machine } \\
\text { Theory }\end{array}$ & $\begin{array}{c}\text { ME } 307 \\
\text { Thermodynamics } \\
\text { and Heat Transfer } \\
\text { ME } 308 \text { Thermo- } \\
\text { fluid Design }\end{array}$ & GLB 301 & $\begin{array}{l}\text { TURK } 101 \\
\text { Turkish II } \\
\\
\text { HIST } 101 \\
\text { History II }\end{array}$ & $\begin{array}{c}\text { ME } 311 \\
\text { Internship I }\end{array}$ \\
\hline 4 & ஸे & $\begin{array}{c}\text { ME } 401 \text { Capstone } \\
\text { Design I } \\
\text { ME } 402 \text { Capstone } \\
\text { Design II }\end{array}$ & $\begin{array}{c}\text { ME } 403 \\
\text { Prototyping } \\
\text { ME } 404 \text { Machine } \\
\text { Design }\end{array}$ & $\begin{array}{c}\text { ME } 405 \\
\text { Mechanism } \\
\text { Design } \\
\text { ME/Free Elective } \\
\text { - Independent } \\
\text { Research }\end{array}$ & $\begin{array}{l}\text { ME/Free Elective } \\
\text { - Independent } \\
\text { Research } \\
\text { ME/Free Elective } \\
\text { - Independent } \\
\text { Research }\end{array}$ & $\begin{array}{c}\text { ME/Free Elective } \\
\text { - Independent } \\
\text { Research } \\
\text { ME/Free Elective } \\
\text { - Independent } \\
\text { Research }\end{array}$ & $\begin{array}{l}\text { OHS } 401 \text { Occup. } \\
\text { Health and } \\
\text { Safety I } \\
\text { OHS } 402 \text { Occup. } \\
\text { Health and } \\
\text { Safety II }\end{array}$ & $\begin{array}{c}\text { ME } 411 \\
\text { Internship II }\end{array}$ \\
\hline
\end{tabular}

Table 2: The Theoretical and Corresponding Applied Course

\begin{tabular}{|c|c|c|}
\hline & \multicolumn{2}{|l|}{ Theoretical and Corresponding applied course } \\
\hline & Theoretical & Applied \\
\hline 1 & ME 101 Technical Drawing & ME 102 Engineering Innovation and Programming \\
\hline 2 & ME 108 Materials Sciences & ME 209 Materials Design \\
\hline 3 & ME 207 Fluid Dynamics & ME 202 Fluid System Design \\
\hline 4 & ME 301 Machine Elements I & ME 302 Machine Elements II \\
\hline 5 & ME 305 System Dynamics and Controls & ME 304 Mechatronics and Measurements \\
\hline 6 & ME 307 Thermodynamics and Heat Transfer & ME 308 Thermo-fluid Design \\
\hline 7 & ME 306 Machine Theory & ME 405 Mechanism Design \\
\hline 8 & ME 403 Prototyping & ME 404 Machine Design \\
\hline
\end{tabular}

conclusion. In order to increase the reliability of the findings, an online questionnaire was applied to approximately 50 mechanical engineering students using the comparison method.

\section{Data Collection Tool}

Two sets of interview forms were prepared by the researcher to determine:

a. The students' experiences with the Make and how this space had contributed to their learning. b. The department of Mechanical Engineering's experience with the space and how it had affected their teaching.

At the same time, the researchers' aim was to reveal the potential of the Make as a space for interdisciplinary studies and a model for the other universities that wish to establish a makerspace. Descriptive research method that includes personal interviews and normative survey were used to evaluate user's perception of the space and depict the situation (Fraenkel et al., 2011). The first set of data was collected through one-on-one meetings with 5 undergraduate students 
from Mechanical Engineering and 3 graduate assistants from Mechanical Engineering who had been using the space. These participants voluntarily attend the study and were interviewed to evaluate their perception of the space. Following that, the researcher interviewed a faculty member from Mechanical Engineering who established the Make. The interviews lasted approximately 30 minutes. The new curriculum was also examined since it was redesigned to encourage students to experiment and learn outside the classroom (Burke, 2015). The results were compiled using the details to create a final conclusion. In order to increase the reliability of the findings from the interviews, a quantitative data was used to further explain qualitative findings (Guest \& Fleming, 2015). For that purpose, an online questionnaire was applied to approximately 50 mechanical engineering students using the mixed method.

\section{Data Analysis}

For this aim, the courses which are included in the curriculum of Mechanical Engineering and the ones that used design-based projects were examined. Since the study follows a qualitative weighted method, the form of the study was interpreted and edited in the light of the data obtained in the process. The researchers used a trained assistant to type the conversations. Interview notes were coded by the researcher and the assistant independently. Four categories were formed: a) the effect of makerspace on the competencies, b) its effect on soft skills, c) the sustainability of a makerspace and d) the need for adequate training. Direct quotations from the interviewees were used to emphasize their opinions.

\section{FINDINGS}

\section{The Effects of Makerspace on Field Competencies}

In the online survey, $80 \%$ of the students stated that they use the Make outside of their courses and expressed their desire to continue their learning with the Make. They stated that the space provided them an environment to apply the theory for better learning. Although the students are satisfied with the independently-run projects that they have been working on so far, they have expressed their desire to work on projects that are embedded in the course work and offer different perspectives in the content knowledge. They also express their desire to use tools other than 3D printers in their projects.

\section{The Effect of Makerspace on Soft Skill}

The interviewed students expressed their desire to work on projects that increase their creativity and support their critical thinking. When they were asked to share at least 3 of the competencies that they are expected to acquire when they graduate, $90 \%$ of mechanical engineering students mentioned creativity and teamwork, $70 \%$ of them mentioned analytical thinking and the ability to initiate, and $50 \%$ of them mentioned being a self-learner and the ability to write a project. As one student expressed:

The main one ... is creativity, which assists the graduate to find alternative solutions for current problems... [although the third one] may sound like creativity, it is still different. I believe
... being able to produce the best quality with the least [effort] and this requires analytical thinking.

They are well aware that these are the skills that industry demands. Undergrad and graduate assistants stated that they benefit from the makerspace and the positive output on their soft skills, such as team work, time management and conflict resolution. However, students expressed their concerns about the operation and the sustainability of the space, which leads us to the third category.

\section{The Sustainability of the Space}

When the academician who set up the space was interviewed, he stated that the space was designed to be operated by Mechanical Engineering students and graduate assistants. Although the students stated that working with upperclass students had accelerated and enhanced their learning processes, they expressed the need for a specialist or a technician working full time in the space. For the sustainability of this specific makerspace there is an urgent need to have an experienced and equipped technician to run the space.

As one student expressed:

... there is a lack of [technician] [access to makerspace is limited] ... the makerspace [should be] easier to access and [institutions should] encourage the multi-department-based projects.

Institutions that want to establish and operate a makerspace in their university campuses should also take into consideration the not-so-positive views of students in order to solve the problems that may arise in the future. The interviewed students stated that there should be strict rules regarding the use of the area. As one student expressed, "... students are not responsible. When we arrive in the morning, we see the pieces left on the table. Individual responsibility is required." Students also advised that if the student is to be employed, the log books should be used to keep track of work.

\section{A Need for an Adequate Training}

The students stressed the lack of training prior on using the space. $70 \%$ of the students stated that the support provided by the department was inadequate. They compensated by teaching themselves through YouTube videos and with the help of the upper-class students.

\section{RESULTS, DISCUSSION and RECOMMENDATIONS}

It can be said that students want more than theoretical knowledge from their engineering education. Therefore, it is essential to provide them with a place for them to be active, creative, engaged and apply what they have learned. As emphasized both in Saorin et al. (2017) and in Hilton et al. (2020), students who spent time in these venues have significantly higher level of confident, self-efficiency, motivation and creativity.

The sustainability and the functioning of these spaces should be taken into consideration when designing these areas. In a study that was conducted in the US, a combination of student support staff and specialized staff personnel was 
found to be the most common staffing model as opposed to the use of specialized staff personnel in Australian academic makerspaces. In this study, the users emphasized the need for specialized staff personnel. However, for institutions that have difficulty in recruiting staff, involving undergraduate and graduate students is of great importance. These students should be trained prior to use of the space and continuous orientation programs should be offered.

The Mechanical Engineering Department took an important step on behalf of engineering education by designing a new curriculum. However, our observations have shown that changing the curriculum from scratch may not increase the use of the space. There is a need for faculty development since not all of the faculty members will have the competency to use these kinds of learning spaces and they need experience to apply new teaching methods. Integrating the makerspace into courses through projects and providing support for faculty members specifically for interdisciplinary projects may provide positive results and will ensure their sustainability of the space.

As mentioned by the students, providing workshops to use the tools and machines is another necessary step that should be taken for the sustainability of the space. Student groups should be supported and asked to design workshops for the space to initiate peer-to-peer learning.

After the report from this study was shared with the administration, in mid 2019, a technician was appointed and the makerspace's hours of operation was expanded from 8am to $5 \mathrm{pm}$ every weekday. The space was moved to a bigger space in order to meet growing demand. It became an interdisciplinary study space for students from various disciplines (Mechanical, Electric Electronics, Material Science and Molecular Biology and Genetics, Computer Engineering).

There are several topics that could be further investigated which would bring different perspectives to the field. Such as,

- Assessing students' engagement with students from other disciplines.

- Assessing students' state of motivation while they are working on their makerspace projects.

- Assessing the engagement level according to the genders.

In Turkey, makerspaces are unlikely to be founded in academic libraries, unlike the models in the USA and Australia. On the other hand, "pop-up" or "mobile" makerspaces might be a good idea to be used in an exploratory stage to assess interest in makerspaces. The model of temporary makerspaces that are compact and inexpensive and easy to establish and take down might be a good sustainable alternative to "test the waters" before implementing a permanent like those adopted by University of Melbourne and Curtin University (Wong \& Partridge, 2016).

\section{ACKNOWLEDGEMENTS}

This work was supported by Department of the Scientific Research Projects, Abdullah Gul University under grant number
SCD-2018-112. Any opinions, findings, and conclusions or recommendations expressed in this material are those of the authors and do not necessarily reflect the views of Abdullah Gul University.

\section{REFERENCES}

Barak, M. (2013). Teaching engineering and technology: cognitive, knowledge and problem-solving taxonomies. Journal of Engineering Design and Technology, 11(3), 316-333. doi: 10.1108/JEDT-04-2012-0020.

Beanland, D., Hadgraft, R. (2014). Engineering Education: Transformation and Innovation. A Monograph commissioned by UNESCO, Melbourne, Australia.

Bengu, E., Emeric, A., Sabuncuoglu, I., Yilmaz, C. (2020). Rethinking higher education for the emerging needs of society. Global Solutions Journal, 5, 178 - 187. Retrieved from https://bit. ly/2M4ynnT

Bengu, E. \& Sebnem, S. (2018). Attitudes of Instructors Towards Active Learning at a New Generation University. In F. N. Seggie, \& T. Kurt (Eds.), Proceedings of Revisiting Higher Education in an Ever-Changing World: 3rd International Higher Education Studies Conference (pp. 44-51). Istanbul: Caretta.

Blackley, S., Sheffield, R., Maynard, N., Koul, R., \& Walker, R. (2017). Makerspace and Reflective Practice: Advancing Preservice Teachers in STEM Education. Australian Journal of Teacher Education, 42(3). doi: 10.14221/ajte.2017v42n3.2

Burke, J. (2015). Making Sense: Can Makerspaces Work in Academic Libraries. Association of College and Research Libraries, 497 - 504.

Dede, C. (2009). Comparing frameworks for "21st century skills". http://sttechnology.pbworks.com/f/Dede_(2010)_Comparing\%20Frameworks\%20for\%2021st\%20Century\%20Skills.pdf

Fraenkel, J. R., Wallen, N. E., \& Hyun, H. H. (2011). How to design and evaluate research in education. New York: McGraw-Hill Humanities/Social Sciences/Languages.

Guest, G. \& Fleming, P. (2015). Mixed Methods Research. In G. Guest, \& E. Namey (Eds.), Public Health research Methods (pp.581-610). Sage. https://doi.org/10.4135/9781483398839. n19.

Hatch, M. (2013). The Maker Movement Manifesto: Rules for Innovation in the New World of Crafters, Hackers, and Tinkerers. McGraw-Hill: first edition.

Hilton, E. C., Talley, K. G., Smith, S. F., Nagel, R. L., \& Linsey, J. S. (2020). Report on engineering design self-efficacy and demographics of makerspace participants across three universities. Journal of Mechanical Design, 142.

Kececi, E. F. (2017). Applied Interdisciplinary Engineering Education Space-AGU Make.

Lanci, S., Nadelson, L., Villanueva, I., Bouwma-Gearhart, J., Youmans, K. L., \& Lenz, A. (2018). Developing a measure of engineering students' makerspace learning, perceptions, and interactions. American Society for Engineering Education. 2018 ASSE Annual Conference \& Exposition, paper ID \#22089.

Myers, J. (2015). Creating Collaborative Spaces at the University of Arizona: Ways to Encourage Interdisciplinary Research and Ideas. University of Arizona, Tuscon, AZ. 
Roffey, T., Sverko, C., Therien, J. (2016) The Making of a Makerspace: Pedagogical and Physical Transformations of Teaching and Learning. ETEC 510 Curriculum Guide.

Sahin, E. \& Tosun, N. (2018). Maker Movement and Applications in Turkey. In S. Gulsecen, C. Selcukcan Erol, Z. Ayvaz Reis, \& M. Gezer (Eds.), Proceedings of Innovations in Learning for the Future: Digital transformation in education (pp. 70-78). Istanbul.

Saorin, J. L., Melian-Diaz, D., Bonnet, A., Carrera, C. C., Meier, C. \& De La Torre-Cantero, J. (2017). Makerspace teaching-learning environment to enhance creative competence in engineering students. Thinking Skills and Creativity, 23, 188-198. doi: 10.1016/j.tsc.2017.01.004

Shay, S. (2012). Conceptualizing curriculum differentiation in higher education: a sociology of knowledge point of view. British Journal of Sociology of Education, 34(4), 563-582, doi: 10.1080/01425692.2012.722285.
Sheffield, R., Koul, R., Blackley, S. \& Maynard, M. (2017) Makerspace in STEM for girls: a physical space to develop twenty-first-century skills. Educational Media International, 54 (2), 148-164. doi: 10.1080/09523987.2017.1362812

Stager, G. (2014). What's the Maker Movement and Why Should I Care? Scholastic Administrator Magazine. http://www. scholastic.com/browse/article.jsp?id=3758336.

Wilczynski, V. (2015). Academic Maker Spaces and Engineering Design. 122nd ASEE Annual Conference \& Exposition. Seattle, WA. Paper ID \# 13724.

Wong, A. \& Partridge, H. (2016) Making as Learning: Makerspaces in Universities, Australian Academic \& Research Libraries, 47(3), 143-159. doi:10.1080/00048623.2016.1228163 